\title{
UPAYA MENINGKATKAN KINERJA MENGAJAR SEKOLAH DASAR SE-KECAMATAN GIRSANG SIPANGAN BOLON
}

\author{
Desi Sijabat \\ Universitas HKBP Nommensen Pematangsiantar, Indonesia. \\ Email: desisijabat9@gmail.com
}

\begin{abstract}
This study aims to determine how much influence academic supervision has on the teaching performance of elementary school teachers in Girsang Sipangan Bolon District. The type of research used is quantitative research, using a simple regression analysis tool. The sample in this study were 35 teachers who teach in elementary schools throughout the Girsang Sipangan Bolon sub-district, using simple random sampling technique.

From the results of the research shows the performance regression equation that is $Y=0.4219+0.43 x$. The magnitude of the influence of academic supervision has a positive direction on performance. This means that if the motivation and academic supervision is increased by one unit, the teacher's performance will change. The measure of supervision ability to explain the variance (movement) of performance is obtained from the value of $R$ Square. Then work motivation and academic supervision can explain the variance (movement) of performance of 0.51 or $51 \%$.

Efforts to improve academic supervision, principals should use appropriate supervision approaches and techniques through harmonious relationships between principals and teachers when conducting supervision.
\end{abstract}

Keywords: Teaching Performance, Academic Supervision.

\begin{abstract}
ABSTRAK
Penelitian ini bertujuan untuk seberapa besar pengaruh supervisi akademik terhadap kinerja mengajar guru Sekolah Dasar se- Kecamatan Girsang Sipangan Bolon. Jenis Penelitian yang digunakan adalah penelitian kuantitatif, dengan menggunakan alat analisis regresi sederhana. Sampel dalam penelitian ini adalah 35 guru yang mengajar di Sekolah Dasar se- Kecamatan Girsang Sipangan Bolon, dengan menggunakan teknik simple random sampling.

Dari hasil penelitian menunjukkan persamaan regresi kinerja yitu $Y=0,4219+0,43 x$. Besarnya pengaruh supervisi akademik mempunyai arah positif terhadap kinerja. Arinya jika motivasi dan supervisi akademi dinikkan satu satuan maka kinerja guru akan mengalami perubahan. Ukuran kemampuan supervisi menjelaskan variansi (pergerakan) kinerja diperoleh dari nilai R Square. Kemudian motivasi kerja dan supervisi akademik bisa menjelaskan variansi (pergerakan) kinerja sebesar 0,51 atau $51 \%$.

Upaya untuk meningkatkan supervisi akademik sebaiknya kepala sekolah menggunakan pendekatan dan teknik supervisi yang tepat melalui hubungan yang harmonis antara kepala sekolah dengan guru-guru saat melakukan supervisi.
\end{abstract}

Kata Kunci: Kinerja Mengajar, Supervisi Akademik

\section{PENDAHULUAN}

Salah satu faktor yang menjadi tolak ukur keberhasilan sekolah adalah kinerja guru dalam mengajar. Kinerja guru memengaruhi usaha dan aktivitas belajar siswa, seperti yang diungkapkan Asroi (2013:12) dalam penelitiannya bahwa faktor yang memberikan konstribusi besar terhadap prestasi belajar siswa adalah berasal dari faktor guru sebesar $36 \%$, sedangkan sisanya adalah faktor manajemen $23 \%$ dan waktu belajar $22 \%$, serta faktor sarana dan prasarana sebesar $19 \%$. Kinerja guru ataupun prestasi kerja adalah suatu hasil kerja yang dicapai seseorang dalam melaksanakan tugas-tugas yang dibebankan kepadanya yang didasarkan atas kecakapan, pengalaman, dan kesungguhan serta waktu. Membahas kualitas dari kinerja guru tidak terlepas dari 
pencapaian hasil belajar. Hal ini karena kinerja guru sangat menentukan keberhasilan proses belajar yang efektif dan efisisen sehingga tujuan pendidikan tercapai dan terwujud dari hasil belajar siswa yang baik pada akhirnya dapat mencetak lulusan yang berkualitas.

Berdasarkan informasi yang penulis peroleh dari Dinas Pendidikan Kecamatan Pantai Cermin Sumatera Utara bahwa terdapat 96 orang guru kelas dari 128 dan sisanya adalah guru bidang studi (agama, olahraga, kesenian) yang bekerja di 16 SD Negeri. Dari data guru tersebut ternyata tidak semua SD yang ada di Kecamatn Pantai Cermin memiliki guru bidang studi agama Kristen, agama Islam dan olahraga, serta kesenian, sehingga untuk mengatasi hal tersebut kepala sekolah memberikan tanggungjawab sepenuhnya kepada guru-guru kelas untuk mengajar semua mata pelajaran yang diajarkan disetiap kelasnya. Karena kepala sekolah beranggapan bahwa seorang guru mampu menguasai semua mata pelajaran yang akan diajarkan kepada peserta didik. Untuk mencapai hasil yang maksimal dari banyaknya tugas dan tanggungjawab dalam pelaksanaan pembelajran di sekolah, seorang guru dituntut untuk lebih profesional.

Kemudian dari 96 guru Pantai Cermin kelas yang bekerja di SD seKecamatan Girsang Sipanganbolon, 56 orang guru yang belum sertifikasi dan selebihnya telah sertifikasi. Banyaknya jumlah guru yang telah sertifikasi ternyata tidak menjamin akreditasi suatu sekolah. Dari 16 sekolah tersebut terdapat 6\% sekolah berakreditas A yaitu sebanyak 1 sekolah, dan terdapat $63 \%$ sekolah berstatus akreditas B yaitu sebanyak 10 sekolah, dan $31 \%$ sekolah yang berstatus akreditas C. Banyaknya sekolah yang belum mencapai akreditas A, tidak terlepas dari guru yang sangat berperan dalam proses pembelajaran, ini menunjukkan kinerja guru dalam mengajar perlu dipertanyakan. Seperti hasil monitoring yang dilakukan pengawas, salah satu faktor rendahnya akreditas SD di Kecamatan Pantai Cermin dari rendahnya skor standar pendidik dan tenaga kependidikan di sekolah-sekolah yang berada di SeKecamatan Girsang Sipanganbolon.

Pelakasanaan supervisi harus dilakukan secara kontinyu mengingat peningkatan kompetensi guru tidak bisa dilakukan secara instan. Sebagai supervisor, kepala sekolah harus mampu memahami karakteristik dan kondisi guru sehingga apa yang menjadi esensi ataupun tujuan dapat tercapai.

Keadaan seperti ini jika terus menerus berlanjut akan memungkinkan guru bekerja kurang baik sehingga kelancaran tugasnya tidak dapat tercapai dengan hasil yang maksimal. Hal demikian juga memengaruhi pencapaian program yang diselenggarakan di SD Se-Kecamatan Girsang Sipanganbolon. Sehubung dengan itulah penulis terdorong untuk mencoba mengkaji dan meneliti tentang "Upaya Meningkatkan Kinerja Guru Sekolah Dasar Se-Kecamatan Girsang Sipanganbolon”.

\section{Kinerja Guru}

Kinerja seseorang dalam menjalankan tugas merupakan sesuatu yang urgen sebagai faktor penentu keberhasilan sebuah lembaga. Antara aktivitas dan kinerja tidak dapat dipisahkan karena ujung dari kinerja seseorang tercermin dari perbuatan yang dilakukan. Artinya sulit dilihat kinerja seseorang tanpa melihat apa yang dilakukannya. Aktivitas atau perilaku seseorang dalam bekerja menunjukkan kinerjanya, perilaku baik, jujur semangat, dan pantang menyerah terhadap tantangan yang dihadapinya berarti menunjukkan kinerja yang baik demi tercapainya tujuan.

Menurut Byars dan Rue (1991:250), "Performance refers to degree of accomplishmemt of the tasks that make up an individual's job. It reflects how well an individual is fulfilling the requirements of a job". Artinya bahwa kinerja mengacu 
pada derajat tingkat penyelesaian tugas yang melengkapi pekerjaan seseorang. Hal ini sejalan dengan pendapat Krisnawanti, Wahyudi \& dkk (2012:54) yang menyatakan bahawa kinerja adalah tingkat keberhasilan sesorang atau kelompok dalam melaksanakan tugas sesuai tanggung jawab dan wewenagnya berdasarkan standar kinerja yang telah ditetapkan selama periode tertentu dalam kerangka mencapai tujuan organisasi.

Sebagai sebuah profesi, kinerja guru sangat berkaitan erat dengan upaya pencapaian tujuan besar dan strategis yakni pendidikan yang berkualitas. Kinerja guru mengacu kepada kemampuan menjalankan tugas-tugas pelayanan pendidikan secara mandiri. Kemampuan tersebut yang dimaksud berbentuk perbuatan nampak, dapat diamati, dan dapat diukur sehinggga satu sama lainnya memiliki ciri dan perbedaan nyata. Perbuatan yang nyata tersebut harus didasari antara lain oleh pengetahuan, wawasan, keterampilan, semangat dan sikap positif.

\section{Faktor-Faktor Yang Memengaruhi Kinerja Guru}

Menurut Abdullah Sandy (2013:20) adapun yang mempengaruhi kinerja guru diantaranya kepribadian dan dedikasi, pengembangan profesi, kemampuan mengajar, antar hubungan dan komunikasi, hubungan dengan masyarakat, kedisiplinan, kesejahteraan. Diperlukan juga keterampilan dan pengetahuan untuk melakukan pekerjaan. Dengan adanya pengetahuan dan keterampilan, memungkinkan individu dapat melakukan pekerjaan dengan tepat dan efisien. Disamping itu faktor persepsi juga memiliki peran penting. Karena jika individu salah mempersepsikan tugas yang diberikan, ada kemungkinan kinerjanya tidak sesuai dengan tujuan-tujuan yang harus dicapai.

Menurut Mahmudin (2015:97) faktor-faktor yang memengaruhi kinerja yaitu:

a. Faktor personalia; meliputi pengetahuan, keterampilan, kemampuan, kepercayaan, motivasi, dan komitmen yang dimiliki setiap individu.

b. Faktor kepemimpinan; meliputi kualitas dalam memberikan dorongan, semangat arahan dan dukungan yang diberikan manajer.

c. Aktor tim; meliputi kualitas semangat dan dukungna yang diberikan oleh rekan kerja, kepercayaan setiap anggota, kekompakan dan keeratan anggota.

d. Faktor sistem meliputi sistem kerja, fasilitas, yang diberikan oleh organisasi, proses organisasi, dan kultur dalam organisasi.

e. Faktor situasional meliputi, tekanan dan perubahan lingkungan.

Knowledge mengacu pada pengetahuan yang dimiliki oleh pegawai, skill mengacu pada kemampuan untuk melakukan pekerjaan, dan motivasi mengacu pada dorongan dan semangat untuk melakukan kerja. Hilangnya salah satu faktor tersebut akan mengganggu kinerja. Pengaruh motivasi dalam pengukuran kinerja sangat penting karena motivasi berperan untuk mengubah perilaku seseorang.

Menurut Hidayat dan Arson (2013:44), kinerja seseorang dipengaruhi oleh dua faktor, yaitu :

a. Faktor internal, faktor yang timbul dalam diri sendiri dan berperan untuk menentukan kualitas kerja dari seseorang.

b. Faktor eksternal, faktor ini memungkinkan seseorang bekerja dengan giat dan sungguh-sungguh untuk menciptakan kualitas kerja berdasarkan faktor dari luar diri sendiri (dorongan dari penilai kinerja).

\section{Supervisi Akademik}

Menurut Arikunto (2010:45) supervisi adalah kegiatan mengamati, mengidentifikasi, mana hal-hal yang sudah benar, dan mana pula yang tidak benar dengan maksud agar tepat dengan tujuan memberikan pembinaan. Supervisi adalah 
pengawasan profesional dalam bidang akademik dijalankan berdasarkan kaidah-kaidah keilmuan tentang bidang kerjanya, memahami tentang pembelajaran lebih mendalam dari sekadar pengawas biasa. Misi utama supervisi pendidikan adalah memberi pelayanan kepada guru untuk mengembangkan mutu pelajaran, memfasilitasi guru agar dapat mengajar dengan efektif.

Sedangkan menurut Darwanto (2013:45) supervisi adalah suatu aktivitas proses pembimbingan dari pihak atasan kepada guru dan personalia sekolah lainnya yang langsung menangani belajar peserta didik, untuk memperbaiki situasi belajar mengajar agar para peserta didik dapat belajar secara efektif dan efisien dengan prestasi yang semakin meningkat. dengan kata lain bahwa supervisi itu merupakan yang direncanakan untuk memperbaiaki dan mengembangkan pengajaran sehingga proses belajar mengajar yang dilakukan oleg guru berlangsung dengan baik dan efektif.

Seperti yang dikatakan Purwanto Ngalim (2009:76) supervisi adalah suatu aktivitas pembinaan yang direncanakan untuk membantu para guru dan pegawai sekolah lainnya dalam melakukan pekerjaan mereka secara efektif. Yang melakukan supervisi adalah kepala sekolah. Jadi nilai-nilai dari supervisi terletak pada perkembangan situasi belajar mengajar yang direfleksikan pada perkembangan yang dicapai peserta didik. Seorang pimpinan mengelola agar tercapai hasil-hasil yang diinginkan atau direncanakan. Keberhasilan akan kegagalan yang disajikan, hasil-hasil ini dipertimbangkan dari segi tujuan yang sudah ditentukan. Hal ini mencakup supervisi, yaitu mengevaluasi pelaksanaan kerja dan jika perlu memperbaiki apa yang sedang dikerjakan untuk menjamin tercapainya hasil-hasil menurut apa yang telah direncanakan. Supervisi adalah dalam bentuk pemeriksaan untuk memastikan bahwa apa yang sudah dikerjakan adalah juga dimaksudkan untuk membuat pimpinan waspada terhadap suatu persoalan potensial sebelum persoalan itu menjadi serius. Supervisi adalah suatu proses dasar, serupa saja di mana pun ia terdapat dan apa pun yang diawasi.

Supervisi dapat didefinisikan sebagai proses untuk menjamin bahwa tujuantujuan oraganisasi dan manajemen tercapai. Ini berkenaan dengan cara-cara membuat kegiatan-kegiatan sesuai yang direncanakan dan supervisi. Seperti yang terlihat dalam kenyataan, langkah awal proses supervisi adalah sebenarnya langkah perencanaan, penetapan tujuan, standar, atau sasaran pelaksanaan suatu kegiatan. Supervisi membantu penilaian apakah perencanaan, pengorganisasian, penyusunan personalia, dan pengarahan telah dilaksanakan secara efektif.

a. Kerja Sama

Kerja sama mengandung suatu pengertian bahwa apa yang dilakukan dalam kegiatan supervisi merupakan untuk mengembangkan usaha bersama atau menurut istilah supervisi 'sharing of idea, sharing of experience', memberi support, mendorong, menstimulasi guru, sehingga mereka merasa tumbuh bersama.

b. konstruktif dan kreatif

Setiap guru akan merasa termotivasi dalam memngembangkan potensi kreativitas kalau supervisi mampu menciptakan suasana kerja yang menyenangtkan, bukan melalui cara-cara menakutkan.

Selain itu Depdiknas (2000:132) turut menejlaskan bahwa ada enam prinsip dalam supervisi yaitu:

1. Demokratis

2. Terpusat pada guru 
Pelaksanaan supervisi yang terpusat pada guru merupakan sasaran pokok yang terdapat dalam kegiatan tersebut. Kegiatan pokok supervisi adalah melakukan pembinaan kepada personil sekolah pada umumnya dan khususnya guru, agar kualitas pembelajaran dapat meningkat.Sebagai dampak dalam meningkatnya kualitas pembelajaran, diharapkan dapat pula meningkatkan prestasi belajar siswa. Dengan meningkatnya prestasi belajar siswa berarti meningkat pula kualitas lulusan sekolah itu.

3. Didasarkan pada kebutuhan guru

Prinsip ini menekankan pada kegiatan supervisi yang dilakukan didasarkan atas kebutuhan guru. Kebutuhan guru berkaitan dengan beberapa keperluan guru yang harus dipenuhi dalam kegiatan mengajar, misalnya kelengkapan alat peraga saat mengajar. Supervisor dapat membantu guru untuk melengkapi alat peraga yang tidak dimiliki guru saat mengajar.

4. Umpan balik

Apabila kepala sekolah merencanakan akan memberikan saran atau umpan balik, sebaiknya diberikan sesegera mungkin agar tidak lupa. Seperti yang diungkapkan Arikunto (2004:20) pada saat memberikan umpan balik, kepala sekolah perlu memberikan kesempatan kepada guru untuk mengajukan pertanyaan atau tanggapan. Dengan demikian akan terjalin hubungan yang erat antara kepala sekolah dengan guru-guru.

5. Bersifat bantuan profesional

Supervisi harus mengarahkan kepada keprofesionalan guru dalam mengajar. Oleh karena itu, seorang supervisi dalam menjalankan tugasnya harus dituntut profesional. dengan tujuan agar kepala sekolah dan guru-guru benar-benar merasakan hasil yang dapat berguna sebab keduanya sama-sama memahami akan tugas dan kewajibanya.

\section{METODE PENELITIAN}

Penelitian ini dilakukan di Sekola Dasar yang berada di Se-Kecamatan Girsang Sipanganbolon. Waktu penelitian ini dilaksanakan selama dua bulan yaitu Oktober 2019 s/d November 2019. Penelitian ini menggunakan pendekatan kuantitatif dengan jenis penelitian korelasional. Artinya menggambarkan pola hubungan antar dua variabel $\mathrm{x}$ dengan $\mathrm{y}$. Penelitian ini bertujuan untuk menganalisis pengaruh motivasi kerja dan supervisi terhadap kinerja guru. Populasi dalam penelitian ini adalah guru yang masih mengajar di sekolah yang berakreditas $\mathrm{B}$ dan $\mathrm{C}$ SeKecamatan Girsang Sipanganbolon, guru kelas 1-6, guru yang sudah Sertifikasi. Maka Jumlah populasi dalam penelitian ini yaitu 35 guru Sekolah Dasar SeKecamatan Girsang Sipanganbolon.

Responden yang mengukur kinerja dan supervisi akademik adalah 35 orang guru Sekolah Dasar se-Kecamatan Girsang Sipangan Bolon. Dengan menggunakan teknik sampling Sensus, di mana semua anggota populasi dijadikan sampel dalam penelitian.

\section{Teknik pengumpulan Data}

Teknik pengumpulan data yang digunakan dalam penelitian ini adalah kuesioner (angket) mengenai supervisi akademik, dan kinerja guru. Skala pengukuran angket yang digunakan yaitu skala Likert dengan rentang skor 1-5 


\section{Uji Validitas dan Reliabilitas Data}

Uji coba instrumen dilakukan kepada guru SD Se-Kecamatan Girsang Sipanganbolon sebanyak 30 orang guru yang tidak termasuk dalam sampel penelitian. Melalui uji coba ini peneliti menemukan instrumen yang valid dan reliabel.

Uji Validitas Instrumen

Untuk menguji butir soal menggunakan korelasi product moment antara skor butir soal dengan skor total. Butir soal dikatakan valid jika $r_{\text {hitung }}>r_{\text {tabel }}$, sebaliknya jika $r_{\text {hitung }}<r_{\text {tabel }}$ maka butir soal dinyatakan tidak valid. Oleh karena itu butir pertanyaan yang tidak valid "di-drop. $r_{\text {hitung }}$ adalah nilai korelasi setiap butir soal, sedangkan $r_{\text {tabel }}$ sebesar 0.361 .

Uji Reliabilitas Instrumen

Untuk menguji tingkat reliabilitas instrumen menggunakan statistik Alpha Cronbach yaitu dengan menganalisis reliabilitas alat ukur dari satu kali pengukuran. Data dikatakan reliabel bila nilai Alpa Cronbach > 0,7.

\section{Analisis Data}

Untuk menguji hipotesis penelitian, perlu dilakukan analisis data. Tahapantahapan dalam analisis data adalah:

Statistik Deskriptif

Sattistik deskriptif adalah menampilkan ringkasan data dalam bentuk ratarata, diviasi standar, range, dan distribusi dari kinerja guru, motivasi guru dan supervisi guru.

Korelasi antara dua variabel

Korelasi antara dua variabel artinya adalah mengukur derajat hubungan linier antara kinerja guru, motivasi guru dan supervisi guru.

Regresi Sederhana

Regresi adalah alat analisis menguji pengaruh variabel independen terhadap variabel dependen. Untuk menguji apakah x memengaruhi y atau tidak yaitu dengan mengunakan uji t. Hipotesis uji t dinyatakan sebagai berikut:

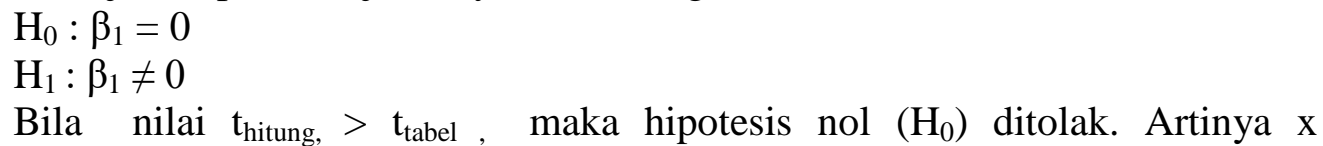
memengaruhi y $\left(\beta_{1} \neq 0\right)$. Besar pengaruh $\mathrm{x}$ terhadap y ditampilkan pada nilai estimasi $\beta$, dengan persamaan sebagai berikut:

Keterangan:

$$
y=\beta_{0}+\beta x
$$

$\mathrm{y}$ : Kinerja guru

$\mathrm{x}$ : Supervisi akademik

$\beta_{0}$ : Konstan atau nilai y bila nilai $\mathrm{x}$ sama dengan nol

$\beta$ : Besarnya pengaruh $\mathrm{x}$ terhadap $\mathrm{y}$

Ukuran kemampuan model bisa menjelaskan variabel dependen diperoleh dari besarnya nilai koefisien determinasi $\left(\mathrm{R}^{2}\right)$. 


\section{HASIL PENELITIAN \\ Kinerja Guru (y)}

Tabel 1 Distribusi nilai variabel Kinerja Guru (y)

\begin{tabular}{ccc}
\hline Interval & Frekuensi & Peresntase \\
\hline & & \\
\hline $4,21-5,00$ & 0 & $0 \%$ \\
\hline $3,41-4,20$ & 0 & $0 \%$ \\
\hline $2,61-3,40$ & 16 & $39 \%$ \\
\hline $1,81-2,60$ & 19 & $61 \%$ \\
\hline $1,00-1,80$ & 0 & $0 \%$ \\
\hline
\end{tabular}

Sumber: Data diolah, November 2019

Tabel menyajikan bahwa skor paling banyak mencapai $61 \%$ terdapat pada interval 1,81-2,60 dengan frekuensi sebanyak 19 orang dari 35 orang, dan $39 \%$ berada pada interval 2,61-3,40 dengan frekuensi sebanyak 16 orang. Lebih jelasnya lagi keadaan kinerja guru akan ditampilkan dalam gambar berikut ini:

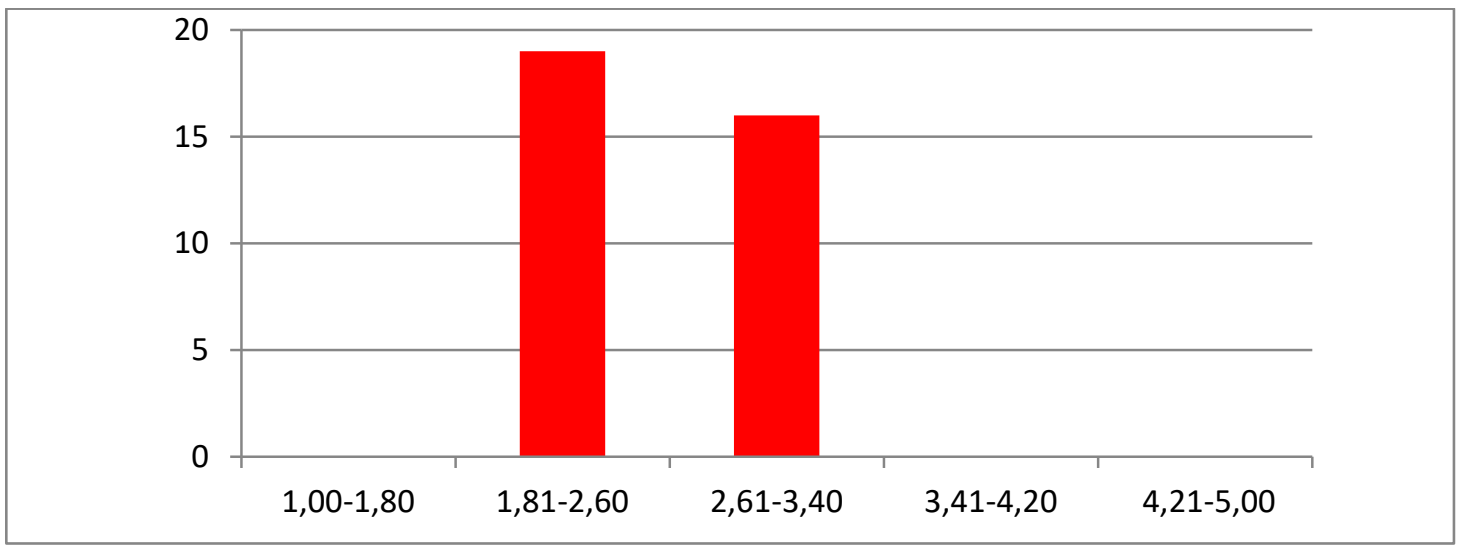

\section{Gambar 1 Histogram Frekuensi Kinerja Guru}

Gambar menyajikan bahwa skor rata-rata penilaian guru tentang kinerja guru tidak ada yang mencapai interval 3,41-4,20 bahkan 4,21-5,00. Artinya masih banyak guru SD Se-Kecamatan Girsang Sipanganbolon yang tidak menunjukkan kinerja yang tinggi. Hal ini disebabkan perencanaan pembelajaran dan pelaksanaan pembelajaran yang dilakukan guru masih rendah. Pada kenyataanya terdapat 19 guru yang mencapai interval 1,81-2,60 dan selebihnya yaitu 16 guru berada pada interval 2,61-3,40. Artinya bahwa dari data tersebut tidak sedikit guru-guru menunjukkan kinerja yang rendah. Penyebab rendahnya kinerja guru adalah masih ada guru-guru menggunakan tujuan pembelajaran yang ada di LKS, kurangnya kemampuan guru dalam memadukan materi pelajaran dengan fenomena-fenomena yang sedang terjadi, kurangnya kemampuan guru dalam menerapkan pembelajaran guru yang bervariasi dan guru fokus pada buku pedomannya, dan kurangnya pengakuan guru terhadap siswa, serta kurangnya kemauan guru menbuat soal-soal yang berbeda dan mirip dengan soal-soal yang digunakan saat menjelaskan materi, dan kurangnya kemauan guru untuk memberikan bimbingan khusus bagi siswa yang memperoleh nilai rendah. 


\section{Supervisi Akademik (x)}

\section{Tabel 2. Distribusi nilai variabel Supervisi Akademik $\left(\mathbf{x}_{2}\right)$}

\begin{tabular}{ccc}
\hline Interval & Frekuensi & Peresntase \\
\hline $4,21-5,00$ & 0 & $0 \%$ \\
\hline $3,41-4,20$ & 0 & $0 \%$ \\
\hline $2,61-3,40$ & 10 & $29 \%$ \\
\hline $1,81-2,60$ & 25 & $71 \%$ \\
\hline $1,00-1,80$ & 0 & $0 \%$ \\
\hline
\end{tabular}

Sumber: Data diolah, November 2019

Tabel menyajikan bahwa skor paling banyak mencapai $71 \%$ terdapat pada interval 1,81-2,60 dengan frekuensi sebanyak 25 orang dari 35 orang, dan $29 \%$ berada pada interval 2,61-3,40 dengan frekuensi sebanyak 10 orang. Lebih jelasnya lagi keadaan kinerja guru akan ditampilkan dalam gambar berikut ini:

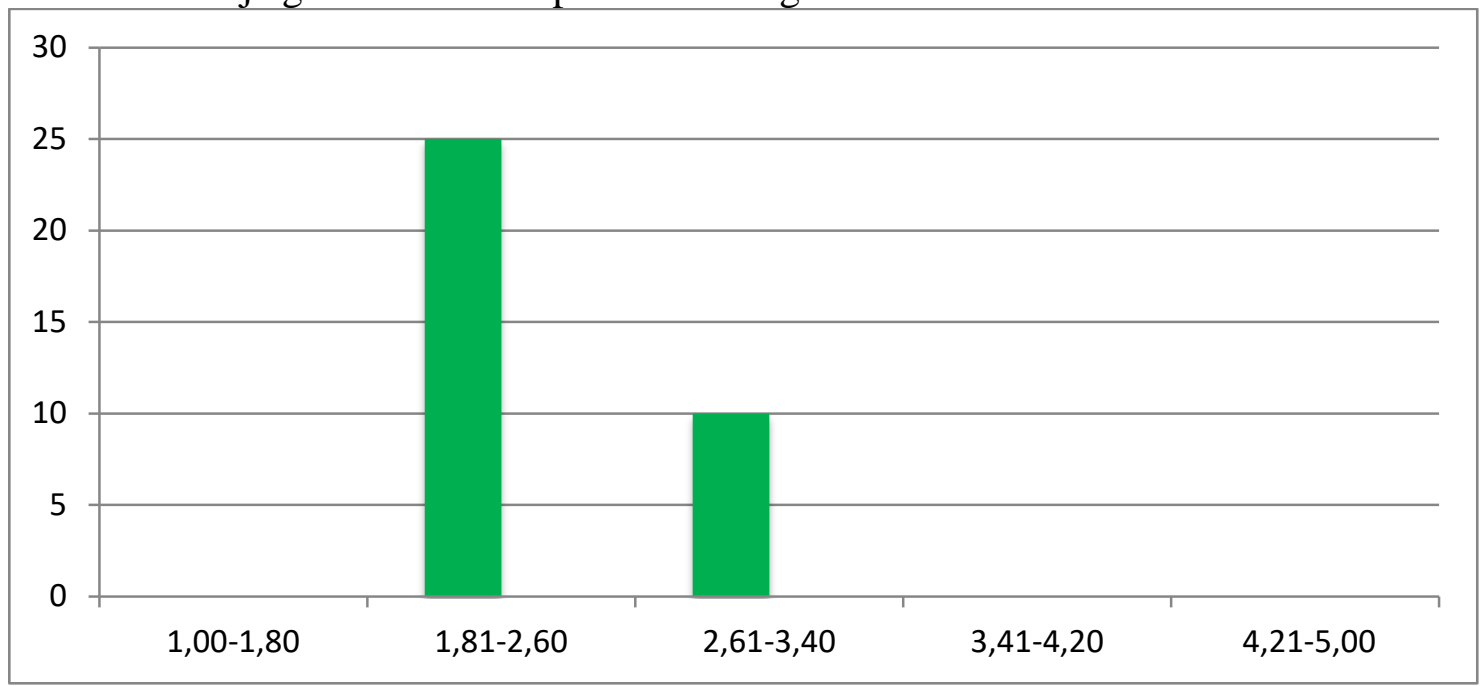

Gambar 2 Histogram Frekuensi Supervisi Akademik

Gambar menyajikan bahwa tidak ada guru yang mencapai skor interval 4,215,00. Artinya masih banyak guru SD Se-Kecamatan Girsang Sipanganbolon yang merasa bahwa pelaksanaan supervisi akademik yang terjadi di tempat mereka mengajar tidak baik, khususnya dalam kerja sama, dan sifat demokratis disekolah yang masih rendah. Pada kenyataanya skor rata-rata yang dicapai guru terkait pelaksanaan supervisi akademik hanya mencapai interval 1,81-2,60 yaitu sebanyak 25 guru, dan selebihnya yaitu 10 guru berada pada interval 2,61-3,40. Data ini menggambarkan bahwa secara umum supervisi akademik SD Se-Kecamatan Girsang Sipanganbolon masih tergolong rendah. Penyebab rendahnya pelaksanaan supervisi di SD SeKecamatan Girsang Sipanganbolon adalah kurangnya keterbukaan guru-guru dalam menceritakan hambatan yang dihadapi saat mengajar kepada kepala sekolah, kepala sekolah menegur guru secara langsung disaat melakukan kesalahan, dan kurangnya kesiapan kepala sekolah menerima kritikan dari guru-guru. Serta kurangnya pembinaan yang dilakukan pada guru-guru dalam hal pengembagan kompetensi guru, misalnya memberikan informasi dan kebebasan pada semua guru mengikuti pelatihan atau seminar secara kontinyu. 


\section{Korelasi Antar Variabel}

Tampilan metriks adalah sebagai berikut:

Tabel 3 Matriks Korelasi

\begin{tabular}{ccccc}
\hline & \multicolumn{4}{c}{ Variabel } \\
\hline \multirow{3}{*}{ Variabel } & \multicolumn{1}{c}{$\mathrm{y}$} & $\mathrm{x}_{1}$ & $\mathrm{x}_{2}$ \\
\cline { 2 - 5 } & $\mathrm{y}$ & 1,00 & $0,59^{* * *}$ & $0,52^{* *}$ \\
\hline
\end{tabular}

Sumber: Data diolah, November 2019

Terdapat hubungan linier antara motivasi dengan kinerja, namun nilai korelasinya sebesar 0,59. Kondisi ini menunjukkan bahwa korelasi ada dan cukup kuat. Selain itu pada tabel 4.6 menyajikan bahwa terdapat hubungan yang linier antara supervisi akademik dengan kinerja guru dengan nilai korelasi sebesar 0,52. Kondisi ini menunjukkan bahwa korelasi antara kinerja guru dengan motivasi kerja dan supervisi akademik ada dan cukup kuat.

\section{Regresi Sederhana}

Tabel menyajikan regresi ganda yang bertujuan untuk menguji pengaruh kedua variabel independen terhadap variabel dependen. Selain itu tabel 4.7 juga dapat menyajikan regresi sederhana yang bertujuan menguji pengaruh motivasi terhadap kinerja, serta pengaruh supervisi akademik terhadap kinerja guru. Hal demikian ditampilkan dalam table sebagai berikut:

Tabel 4 Hasil Analisis Regresi Supervisi Akademik Terhadap Kinerja Guru

\begin{tabular}{ccc}
\hline & \multicolumn{2}{c}{ Kinerja Guru } \\
\hline Variabel & Koefisien & 95\% Confidence Interval \\
\hline Konstan & 0,42 & {$[0,41-0,43]$} \\
\hline Supervisi akademik & $0,43^{* * *}$ & {$[0,42-0,44]$} \\
\hline R-kuadrat & 0,51 & \\
\hline F & $16,31^{* *}$ & \\
\hline
\end{tabular}

Sumber: Data diolah, November 2019

Berdasarkan tabel bahwa besarnya pengaruh supervisi akademik terhadap kinerja sebesar 0,43, artinya koefisien regresi supervisi akademik mempunyai arah positif dalam pengaruhnya terhadap kinerja guru. dimana jika nilai supervisi akademik dinaikkan satu, maka kinerja guru SD Se-Kecamatan Girsang Sipanganbolon akan terjadi kenaikan sebesar 0,43. Selanjutnya, tabel 4.7 dapat diketahui persamaan regresi yang diperoleh variabel kinerja yaitu $y=0,4219+0,43 x$. Besarnya pengaruh supervisi akademik mempunyai arah positif terhadap kinerja. Arinya jika motivasi dan supervisi akademi dinikkan satu satuan maka kinerja guru akan mengalami perubahan. Dalam 
tabel 4.7 juga diperoleh taraf signifikan $0,000<0,05$, artinya bahwa supervisi akademik dapat menjelaskan kinerja guru. Ukuran kemampuan supervisi menjelaskan variansi (pergerakan) kinerja diperoleh dari nilai R Square. Kemudian motivasi kerja dan supervisi akademik bisa menjelaskan variansi (pergerakan) kinerja sebesar 0,51 atau $51 \%$. Artinya bahwa supervisi akademik dapat mejelaskan variansi (pergerakan) kinerja sebesar $51 \%$, sedangkan $49 \%$ dapat dijelaskan faktor-faktor lain yang tidak dibahas dalam penelitian ini.

\section{Pembahasan}

Berdasarkan hasil kuesioner menunjukkan bahwa supervisi akademik di SD Se-Kecamatan Girsang Sipanganbolon masih tergolong rendah dengan nilai rata-rata sebesar 2.53. Pada kenyataanya hubungan yang akrab antara kepala sekolah dengan guru-guru masih rendah, hal ini tercermin dari lebih banyaknya waktu luang yang digunakan kepala sekolah di dalam ruangannya untuk mengerjakan tugas daripada bersama sesama guru, begitu juga dengan guru-guru masih seringberada di ruangan kelas saat istrahat. Hal demikian menunjukkan kurang terjalinnya hubungan yang baik antar sesama guru dengan kepala sekolah.. sehingga kurangnya keterbukaan antara sesama guru dengan kepala sekolah. Ketika guru menghadapi masalah atau hambatan dalam menghadapi siswa, guru tersebut memilih untuk membiarkan hal tersebut dan berusaha menyelesaikan sendiri tanpa meminta masukkan dari kepala sekolah dan sesama guru.

Dalam indikator musyawarah masih tergolong rendah, hal ini tercermin saat melakukan rapat setiap semester untuk mengetahui perkembangan kelas, kepala sekolah lebih dominan berbicara dan kepala sekolah selalu memimpin rapat sehingga guru-guru kurang berpartisipasi dalam rapat. Namun, dalam hal membantu guru dalam pengembangan pembelajaran sudah tergolong cukup tinggi khususnya membantu serta membimbing guru dalam mengevaluasi pembelajaran siswa misalnya memeriksa daftar nilai siswa. Selain itu, kepala sekolah juga merasa bertanggung jawab dalam menyediakan buku-buku terbaru sebagai pedoman guru-guru saat mengajar. Tetapi dalam hal melengkapi alat peraga, kepala sekolah memberikan tanggung jawab sepenuhnya kepada guru-guru. sehingga guru bebas menggunakan media dan metode belajar di dalam kelas.

Begitu juga dalam indikator menstimulasi guru sudah tergolong tinggi, dimana kepala sekolah mulai menunjukkan sikap disiplin dengan tiba di sekolah tepat waktu hal ini dapat memicu guru agar meniru kepala sekolah, dan ternyata tidak sedikit guru mengikuti hal tersebut tanpa ada paksaan dari kepala sekolah. Selain itu kepala sekolah juga memberikan penghargaan bagi guru-guru kelas yang berhasil mencapai nilai tertinggi siswa setiap semester, dengan tujuan dapat memicu guru agar mau bekeja sama untuk meningkatkan kualitas pembelajaran di setiap kelas.

Namun dalam indikator membina guru masih tergolong rendah. Misalnya kurangnya kesempatan yang diberikan kepada guru untuk mengikuti pelatihan, serta kurangnya informasi yang di berikan guru mengenai peningkatan pangkat guru. Tetapi kepala sekolah sangat menekankan dan memperhatikan kompetensi mengajar guru. Jika hal tersebut terus berlanjut tanpa adanya upaya untuk memperbaiki keenam indikator tersebut maka supervisi akan semakin menurun sehingga berdampak pada kinerja guru.

Pendapat di atas dibuktikan dengan hasil penemuan dalam penelitian ini, yang menunjukkan bahwa supervisi akademik memengaruhi kinerja guru sebesar 3,43, artinya jika supervisi akademik meningkat maka kinerja guru juga akan meningkat. 
Sebaliknya jika supervisi akademik menurun maka kinerja guru akan mengalami penurunan. Seperti yang diungkapkan oleh Uno (2015:70) dalam hasil penelitiannya bahwa supervisi kepala sekolah yang berlangsung baik terhadap guru akan mengairahkan guru untuk meningkatkan kinerjanya dalam mengajar. Selain itu Eny (2012:2) dalam penelitiannya yang mengemukakan bahwa kepala sekolah sebagai supervisor memegang peran penting dalam pembinaan dan membantu guru agar dapat meningkatkan fungsinya secara profesional berkenaan dengan pembelajaran.

Dalam melakukan supervisi kepala sekolah dituntut agar dapat menggunakan pendekatan dan teknik supervisi yang tepat melalui hubungan yang harmonis, serta memberikan kesempatan pada guru untuk mengemukakan pendapat. Kepala sekolah dan guru bekerja sama dalam memecahkan masalah, kepala sekolah yang menggunakan pendekatan kekeluargaan akan membuat guru lebih giat meningkatkan proses pembelajaran sehingga mutu pendidikan akan baik.

\section{PENUTUP}

Terdapat pengaruh supervisi akademik terhadap kinerja guru sebesar 0,43 . Hal ini diperoleh dari nilai $\beta_{2}$ sebesar 0,43 , artinya jika supervisi akademik meningkat maka kinerja guru juga akan meningkat. Sebaliknya jika supervisi akademik menurun maka kinerja guru akan mengalami penurunan. Penyebab rendahnya supervisi akademik di sekolah adalah kurangnya keterbukaan guru-guru dalam menceritakan hambatan yang dihadapi saat mengajar kepada kepala sekolah. Selain itu kepala sekolah juga langsung menegur guru secara langsung saat melakukan kesalahan, kurangnya pembinaan yang dilakukan kepala sekolah kepada guru-guru dalam hal pengembangan kompetensi guru, misalnya memberikan informasi dan kebebasan kepada semua guru untuk mengikuti pelatihan atau seminar secara kontinu.

Supervisi akademik yang berlangsung baik kepada guru akan mengairahkan guru untuk meningkatkan kinerjanya dalam mengajar. Supervisi yang diharapkan mampu meningkatkan kinerja guru adalah supervisi yang bersifat demokratis, contohnya terjalinnya hubungan yang akarab dengan memanfaatkan waktu istrirahat menjalin komunikasi antara kepala sekolah dengan guru-guru, serta saling terbuka terkait hambatan yang dihadapi saat melakukan tugasnya, sehingga guru yang lain dan kepala sekolah saling memberi masukkan yang pada akhirnya dapat meningkatkan kinerja guru dalam mengajar. Selain itu ketika kepala sekolah melakukan supervisi didalam kelas, kepala sekolah lebih memfokuskan pada masalah yang dihadapi guru saat mengajar bukan pada gurunya. Sehingga ketika kepala sekolah melakukan hal tersebut, maka guru akan merasa diperhatikan dan dihargai yang pada akhirnya guru akan lebih semangat mengajar dengan adanya supervisi yang dilakukan oleh kepala sekolah. Dengan demikian jika supervisi akademik yang dilakukan oleh kepala sekolah ditingkatkan maka kinerja guru dalam proses pembelajaran juga akan dapat meningkat.

\section{DAFTAR PUSTAKA}

Abdullah, Sandy. (2013). Penilaian Kinerja Profesi Guru dan Angka Kreditnya. Yogyakarta: Gava Media.

Anderson,Robert J, \&Gerald R. Firth, \&Richard F. Neville. (1981). Instructional Supervision. Boston: Alyn and Becon.

Anoraga, Pandji. (2006). Psikologi Kerja. Jakarta: Rineka Cipta.

Arikunto, Suharsini. (1993). Prosedur Penelitian Suatu Pendekatan Praktik. Jakarta: Bina Aksara. 
Arikunto (2010). Dasar-dasar Evaluasi Pendidikan. Jakarta. Bumi Aksara.

Asroi, (2013). Study Tentang Kinerja mengajar Guru: Analisis Pengaruh Kepemimpinan Kepala Sekolah Madrasah, Budaya, dan Motivasi Terhadap Kinerja Mengajar Guru Madrasah Aliyah se-Kota Bekasi. Disertasi. UPI

Byars, L. L, \& Rue, L. W. (1992). Human Ressouces management. (3rd ed). Boston: Irwin In.

Bernardin, J.H. \& Russel, J.E. A (1993). Human Resource Management.Singapore: Mc Graw-Hill.

Burton, WH, dan Bruckner, Lee J.(1955). Supervision. New York: Appleton Century Craff, Inc.

Darwanto, \& Farid Mohammad. (2013). Konsep Dasar Manajemen Pendidikan di Sekolah. Yogyakarta. Gava Media.

Deborah, Kapcha. (2018). Performance. The Journal Of American Folklore. Vol 108, (430) November 2019. http://www.stor.org/stable/541657.

Depdiknas. (2000). Panduan Manajemen Sekolah. Jakarta: Dirjen Dikdasmen.

Djunaedi, (2008). Hubungan Kepemimpinan dengan Kinerja Karyawan Pada PT. Tempo Scan Pacificn Surabaya. Vol.29. 285. Maret. http//proquest.umi.com/pqdweb.

Fraenkle, Wallen \& Hyun. (2012). How To Design and Evaluation Research in Education(8th ed). McGraw-Hill.

Hidayat Syarif dan Asroi. (2013). Manajemen Pendidikan Sustansi dan Impleme tasi dalam Praktik Pendidikan di Indonesia. Tangerang: Pustaka Mandiri.

Solihin, A.M (2007). Pengaruh Motivasi Kerja dan Kompetensi Pedagogik terhadap Kinerja Mengajar Guru Bantu sekolah Menengah Pertama di Kabupaten Tasikmalaya. Tesis. Program Pascasarjana UPI.

Subagyo, Andreas. (2004). Pengantar Riset Kuantitatif dan Kualitatif. Bandung: Kalam Kudus.

Sugiyono. (2013). Metode Penelitian Pendidikan Pendekatan Kuantitatif, Kualitatif, dan $R \& D$. Bandung: Alfabeta.

Sutrisno, Edy. (2011). Budaya Organisasi. Jakarta: Kencana.

Teta, Jenar. (2 Oktober 2012). Pengaruh Supervisi Kepala Sekolah dan Fasilitas Mengajar Guru terhadap Kinerja Guru SMA Negeri 2 Sukoharjo tahun pelajaran 2010/2011. Jurnal. http//proquest. umi. com/pqdweb.

Wiles, John and Bondi,Joseph. (1986). Supervision: A Guide to Practice. Columbus: Charles E. Merrill Pub.

Yamin Martinus dan Maisah. (2010). Standarisasi Kinerja Guru. Jambi: Gaung Persada 